\title{
Functional Properties of PSE (Pale, Soft, Exudative) Broiler Meat in the Production of Mortadella
}

\author{
Cassiana Kissel ${ }^{1}$, Adriana Lourenço Soares ${ }^{1}$, Alessandro Rossa ${ }^{2}$ and Massami \\ Shimokomaki $^{{ }^{*}}$ \\ ${ }^{I}$ Departamento de Ciência e Tecnologia de Alimentos; Universidade Estadual de Londrina; 86051-970; Londrina- \\ PR - Brasil. ${ }^{2}$ Universidade Estadual de Londrina; Rua Cláudio Zatta, 35; Cafelândia - PR - Brasil
}

\begin{abstract}
This work was carried out in order to evaluate whether the functional properties of broiler meat are affected by the factors that lead to PSE (Pale, Soft, Exudative). PSE meat was characterized by pH and L* values, and mortadella formulations consisted of isolated soy protein, sodium tripolyphosphate, and cassava starch in addition to PSE and normal meats. The functionality of the meat was evaluated by examining the water holding capacity (WHC), texture profile, emulsion stability (ES) and color of the final products. The results show that in mortadella prepared with PSE meat, the protein denaturation affected the ES. Additives are necessary to enhance the functional properties of PSE meat.
\end{abstract}

Key words: mortadella, water holding capacity, texture profile, meat color, emulsion stability

\section{INTRODUCTION}

It is well known that PSE conditions in broiler meat result from the denaturation of myofibril proteins. This denaturation is caused by rapid postmortem muscle glycolysis, which lowers the $\mathrm{pH}$ of the meat while the carcass is still warm (Olivo et al. 2001, Barbut, 2008). The occurrence of PSE meat in birds may be affected by a mutation in the ryanodine receptor gene but also depends on several aspects of pre-slaughter management (Chang et al. 2004, Oda et al. 2009). Transport conditions during the trip from the farm to the slaughterhouse, such as showering at the farm, heat, acceleration, vibration, movement, impact, food and water deprivation, social disruption, and noise, are especially important
(Mitchell and Kettewell, 1998). In fact, heat stress during truck transport is one of the main causes of PSE (Mitchell and Kettewell, 1998, Langer, et al, 2009, Simões et al., 2009). PSE meat occurs around the world: in the USA, Woelfel et al. (2002) reported that PSE occurs in 30-50\% of broiler meat and in Brazil, PSE was found in approximately $22 \%$ of broiler meat (Soares et al., 2003). Water Holding Capacity (WHC) is the main property examined in efforts to find a protein that can stabilize a meat emulsion affected by PSE meat abnormality. The addition of additives such as starch (Zhang and Barbut, 2005), collagen, soy protein and carrageenan seem to improve this property, although Woelfel and Sams (2001) could not find any improvement from marinating the meat. The objective of this work was to evaluate

\footnotetext{
* Author for correspondence: mshimo@uel.br
} 
the emulsion properties of broiler chicken PSE meat in the production of mortadella.

\section{MATERIALS AND METHODS}

\section{Samples}

Samples of broiler breast fillet (Pectoralis major) were collected 24 hours post-mortem from the commercial line of a broiler meat company located in the south of Brazil.

\section{Mortadella processing}

Both PSE and normal meats were processed with and without the addition of other ingredients. These ingredients included cassava starch $(3.0 \%)$, isolated soy protein (4.0\%), and sodium tripolyphosphate $(0.20 \%)$. Mechanically deboned chicken meat $(23.0 \%)$, broiler skin $(11.67 \%)$, ice $(15.0 \%)$, salt $(1.8 \%)$, sugar $(0.6 \%)$, sodium eritorbate $(0.2 \%)$, curing salt $(0.25 \%)$, clove of garlic $(0.27 \%)$, white pepper powder $(0.08 \%)$, paprika powder $(0.06 \%)$ and coriander powder $(0.07 \%)$ were also added. Either PSE meat or normal meat was added in an amount that would bring each formulation to $100 \%$. The emulsion was comminuted in the cutter (Brasiaço) and mortadellas were packed in artificial tripe, cooked in a programmed oven (MEG50 Ibrasmak), and cooled in tap water for 15 minutes. The final mortadellas each weighed approximately $800 \mathrm{~g}$ and were stored at $5-7^{\circ} \mathrm{C}$ before chemical analysis was conducted in triplicate.

\section{Color measurement}

A Minolta CR400 colorimeter (Minolta Corp., Ramsey, NJ) was used to evaluate color and $\mathrm{L}^{*}$ (lightness) on the posterior surface of the intact skinless breast muscles at 24 hours post-mortem. The $\mathrm{L}^{*}$ values were measured at three different sites on the same sample as described by Olivo et al., (2001).

\section{pH Measurement}

$\mathrm{pH}$ was measured by inserting electrodes into the breast muscle using a portable digital $\mathrm{pH}$ meter with 0.01 units resolution (PH-720, Instrutherm). Analyses were performed twice at 24 hours postmortem (Olivo et al., 2001).

\section{Sample classification}

Samples were classified as either PSE or normal meat by measuring the $\mathrm{pH}$ and lightness $\left(\mathrm{L}^{*}\right)$ as described elsewhere (Soares et al. 2002). PSE samples presented values of $\mathrm{L}^{*}{ }_{24 \mathrm{~h}} \geq 53.0$ and $\mathrm{pH}$ $\leq 5.80$ and normal meat samples had values of 44.0 $<\mathrm{L}^{*}{ }_{24 \mathrm{~h}}<53.0$ and $\mathrm{pH}>5.80$.

\section{Water Holding Capacity (WHC) measurement}

WHC was determined based on the technique described by Hamm (1960). Twenty-four-hour post-mortem samples were collected from the cranial side of the breast fillets and were cut into $2.0 \mathrm{~g}( \pm 0.10)$ cubes. The samples were analyzed twice. They were first carefully placed between two filter papers and then left under a $10 \mathrm{~kg}$ weight for $5 \mathrm{~min}$. The samples were weighed and WHC was determined from the exudate water weight using the following formula: $100-[(\mathrm{Wi}$ Wf / Wi) x100], where Wi and Wf were the initial and final sample weights, respectively.

\section{Mechanical properties measurement:}

Mechanical properties were analyzed according to the parameters described by Civille and Szczesniak (1973). These parameters included hardness, springiness, cohesiveness, and chewiness (chewiness $=$ hardness $\mathrm{x}$ cohesiveness $\mathrm{x}$ springiness). Samples were cut into cylinders (3 $\mathrm{cm}$ in diameter and $2.2 \mathrm{~cm}$ long) and analyzed on a texturometer (TATX-2i with probe P035).

\section{Emulsion stability (ES) measurement}

Emulsion stability (ES) was measured immediately after the cutter phase as described in Olivo et al. (1996). The ES was measured according to the method described by Lin and Zayas (1987). Briefly, $25 \mathrm{~g}$ of the emulsion meat was weighed in centrifuge tubes, subjected to a thermal treatment of $70^{\circ} \mathrm{C}$ for 30 minutes and centrifuged at $4000 \mathrm{rpm}$ for 3 minutes. The measured supernatant was expressed in percent of emulsion stability.

\section{Statistical analysis}

The results were analyzed using the Statistica 6.0 program. A Student's $t$-test was performed at the level of $5 \%$ probability in order to observe significant differences between the PSE and normal meat formulations. 


\section{RESULTS AND DISCUSSION}

\section{PSE and normal meat samples}

Table 1 presents values of $\mathrm{L}^{*}, \mathrm{a}^{*}, \mathrm{~b}^{*}$ and $\mathrm{pH}$ in PSE and normal breast fillets at 24 hours post- mortem. As expected, $\mathrm{L}^{*}, \mathrm{a}^{*}, \mathrm{~b}^{*}$ and $\mathrm{pH}$ values were different in the two samples $(p<0.05)$. The PSE meat had a lower $\mathrm{pH}$ and a lower $\mathrm{a}^{*}$ value, as reported in other experiments (Olivo et al., 2001, Soares et al. 2003, Guarnieri et. al. 2004).

Table 1 - Mean values of $\mathrm{L}^{*}, \mathrm{a}^{*}, \mathrm{~b}^{*}$ and $\mathrm{pH}$ in 24-h post-mortem PSE and normal broiler breast fillets.

\begin{tabular}{lcccc}
\hline & $\mathbf{L}^{*}$ & $\mathbf{a}^{*}$ & $\mathbf{b}^{*}$ & $\mathbf{p H}$ \\
\hline PSE & $57.63^{\mathrm{a}} \pm 2.37$ & $2.11^{\mathrm{b}} \pm 2.10$ & $5.46^{\mathrm{b}} \pm 2.51$ & $5.77^{\mathrm{b}} \pm 0.09$ \\
Normal & $51.42^{\mathrm{b}} \pm 1.24$ & $7.26^{\mathrm{a}} \pm 3.04$ & $6.74^{\mathrm{a}} \pm 1.64$ & $5.93^{\mathrm{a}} \pm 0.07$ \\
\hline
\end{tabular}

${ }_{a, b}$ Means followed by different letters in the same column differ significantly by the Student's $t$-test at the level of $5 \%$ probability.

Table 2 presents the ES, color, WHC, and mortadella texture profile for both PSE and normal meats with and without the addition of cassava starch, isolated soy protein and sodium tripolyphosphate. The condition of PSE promoted a lower ES $(p<0.05)$ as a result of the denaturation of myofibril proteins, which was reflected in the sample's color (shown in Table 1). Values of WHC did not differ significantly between the two formulations. Similar results were observed by Daigle (2005) in Delicatessen Rolls that were produced from normal and PSE turkey meats. Also, the texture profile, as measured by hardness, springiness, cohesiveness, and chewiness, was not significantly different. This finding suggests that the addition of ingredients such as MDCM, skin and spices decreased the differences between the two mortadella formulations. The color of mortadella that was processed with PSE meat presented values of $L^{*}$ that were significantly higher than those in the product produced with normal meat. The $a^{*}$ and $b^{*}$ values in the mortadella produced with PSE meat were significantly lower than in the product produced with normal meat. These differences indicate that the product's color was dictated directly by the conditions of the raw material, and additional ingredients only weakly contributed to color changes (Table 1).

Tables 2 and 3 present the ES, color, WHC, and mechanical properties of mortadellas that were processed with PSE and normal meats with and without the addition of cassava starch, isolated soy protein and sodium tripolyphosphate. ES was significantly higher in the mortadella prepared with normal meat, suggesting that the additional ingredients were not able to improve the functional properties of the PSE meat. However, Table 2 shows that in mortadella formulations without these ingredients, the ES value of PSE mortadella was significantly higher than in the mortadella made with normal meat. The ES value was even higher when cassava starch, isolated soy protein and tripolyphosphate were added, which suggests that soy protein acts synergistically as an emulsifier. This improves the final product's ES, as previously observed by Wang et al. (2000).

Table 2 - Values of Emulsion Stability (ES), L*, a*, b*, WHC, Hardness, Springiness, Cohesiveness, and Chewiness of mortadellas processed with PSE and Normal meats without the addition of cassava starch, isolated soy protein and sodium tripolyphosphate.

\begin{tabular}{cccccccccc}
\hline & ES $(\%)$ & $\mathbf{L}^{*}$ & $\mathbf{a}^{*}$ & $\mathbf{b}^{*}$ & WHC (\%) & Hard. & Spring. & Cohes. & Chew. \\
\hline MPWo & $90.99^{\mathrm{b}}$ & $68.18^{\mathrm{a}}$ & $12.80^{\mathrm{b}}$ & $12.75^{\mathrm{a}}$ & $60.61^{\mathrm{a}}$ & $33.97^{\mathrm{a}}$ & $0.85^{\mathrm{a}}$ & $0.37^{\mathrm{a}}$ & $10.53^{\mathrm{a}}$ \\
& \pm 0.67 & \pm 0.60 & \pm 0.27 & \pm 0.16 & \pm 5.12 & \pm 5.40 & \pm 0.04 & \pm 0.02 & \pm 1.29 \\
MNWo & $92.87^{\mathrm{a}}$ & $67.42^{\mathrm{b}}$ & $13.31^{\mathrm{a}}$ & $12.61^{\mathrm{a}}$ & $65 ., 90^{\mathrm{a}}$ & $28.13^{\mathrm{a}}$ & $0.83^{\mathrm{a}}$ & $0.40^{\mathrm{a}}$ & $9.28^{\mathrm{a}}$ \\
& \pm 0.49 & \pm 0.18 & \pm 0.20 & \pm 0.24 & \pm 4.00 & \pm 1.81 & \pm 0.4 & \pm 0.07 & \pm 2.07 \\
\hline
\end{tabular}

\footnotetext{
a,b Means followed by the same letter within the column are equal by the student test.

MPWo = Mortadella processed with PSE meat without addition of cassava starch, isolated soy protein, and sodium tripolyphosphate.

MNWo = Mortadella processed with Normal meat without addition of cassava starch, isolated soy protein, and sodium tripolyphosphate.

Hard $=$ Hardness $(\mathrm{N})$; Spring $=$ Springness; Cohes $=$ Cohesiveness; Chew $=$ Chewiness.
} 
Table 3 - Values of Emulsion Stability (ES), L*, a*, b*, WHC, Hardness, Springiness, Cohesiveness, and Chewiness of mortadellas processed with PSE and Normal meats with the addition of cassava starch, isolated soy protein and sodium tripolyphosphate.

\begin{tabular}{cccccccccc}
\hline & ES $(\%)$ & $\mathbf{L}^{*}$ & $\mathbf{a}^{*}$ & $\mathbf{b}^{*}$ & WHC $(\%)$ & Hard. & Sprin. & Cohes. & Chew. \\
\hline MPWi & $97.72^{\mathrm{b}}$ & $66.59^{\mathrm{a}}$ & $11.89^{\mathrm{b}}$ & $15.81^{\mathrm{b}}$ & $77.79^{\mathrm{a}}$ & $106.14^{\mathrm{a}}$ & $0.87^{\mathrm{a}}$ & $0.66^{\mathrm{a}}$ & $61.42^{\mathrm{a}}$ \\
& \pm 0.05 & \pm 0.19 & \pm 0.04 & \pm 0.12 & \pm 1.62 & \pm 8.50 & \pm 0.02 & \pm 0.02 & \pm 6.41 \\
MNWi & $98.02^{\mathrm{a}}$ & $65.50^{\mathrm{b}}$ & $12.26^{\mathrm{a}}$ & $16.25^{\mathrm{a}}$ & $79.42^{\mathrm{a}}$ & $78.17^{\mathrm{b}}$ & $0.85^{\mathrm{a}}$ & $0.54^{\mathrm{a}}$ & $36.32^{\mathrm{b}}$ \\
& \pm 0.03 & \pm 0.50 & \pm 0.07 & \pm 0.17 & \pm 1.29 & \pm 6.50 & \pm 0.04 & \pm 0.15 & \pm 12.43 \\
\hline
\end{tabular}

${ }_{\mathrm{a}, \mathrm{b}}$ Means followed by the same letter within the same column are equal by the student test.

MPWi = Mortadella processed with PSE meat with addition of cassava starch, isolated soy protein, and sodium tripolyphosphate MNWi = Mortadella processed with Normal meat with addition of cassava starch, isolated soy protein, and sodium tripolyphosphate.

Hard = Hardness $(\mathrm{N})$; Spring = Springness; Cohes = Cohesiveness; Chew $=$ Chewiness.

By comparing Tables 2 and 3, which show WHC values without and with the addition of other ingredients, respectively, it can be observed that the addition of ingredients increased the WHC values proportionally. This indicates that both salt and tripolyphosphate possibly increased the water linkage within the meat emulsion, as reported by Barbut et al. (2008).

Mortadella processed with PSE meat presented values of hardness and chewiness that were significantly higher than those of the mortadella processed with normal meat. The additional ingredients enhanced the hardness and chewiness of the PSE meat product. Hachmeister and Herald (1998) also found that modified starch contributed to the hardness texture profile of a meat product made from a turkey emulsion.

\section{CONCLUSION}

Although the technological functional properties of broiler PSE meat are weak, they are strengthened by the addition of other mortadella ingredients. As a result, this abnormal meat can be used as a fresh raw material in the production of a broiler breast meat emulsion.

\section{RESUMO}

Este trabalho foi realizado para avaliar o efeito dos fatores que conduzem à formação das carnes PSE (Pale, Soft, Exudative) sobre as propriedades funcionais da carne de frango. Carnes PSE foram caracterizadas pelos valores de $\mathrm{pH}$ e $\mathrm{L}^{*} \mathrm{e}$ as formulações da mortadela consistiram de proteina isolada de soja, trifosfato de sódio, amido de mandioca e a adição das carnes normal e PSE. A funcionalidade da carne foi avaliada medindo a capacidade de retenção de água (CRA), perfil de textura, estabilidade de emulsão (EE), e cor dos produtos finais. Os resultados mostraram que na mortadela preparada com carnes PSE, as proteinas desnaturadas afetaram a EE. Aditivos são necessários para potencializar as propriedades funcionais da carne PSE.

\section{REFERENCES}

Barbut, S.; Sosnicki, A. A.; Lonergan, S. M.; Knapp, T.; Ciobanu, D. C.; Gatcliffe, L. J.; Huff-Lonergan, E.; Wilson, E. W. (2008), Progress in reducing the pale, soft and exudative (PSE) problem in pork and poultry meat. Meat Science, 79, 46-63.

Chiang, W.; Allison, C. P.; Linz, J.E.; Strasburg, G. M. (2004), Identification of two $\square$ RyR alleles and characterization of alpha RyR transcript variants in turkey skeletal muscle. Gene, 330, 177-184

Civille, G. V., Szczesniak, L. (1973), Guindelines to training a texture profile panel. Journal of Texture Studies, 4, 204-223.

Daigle, S. P. (2005), PSE poultry breast enhancement through the utilization of poultry collagen, soy protein, and carrageenan in a chunked and formed deli roll. Thesis. Faculty of Virginia Polytechnic Institute and State University, Blacksburg, Virginia.

Hachmeister, K. A.; Herald, T. J. (1998). Thermal and rheological properties and textural attributes of reduced-fat turkey batters. Poultry Science, 77, 632638.

Hamm, R. (1960), Biochemistry of meat hydration. Advances in Food Research, 10, 2, 335-443. 
Langer, R. O. S., Simões, G. S., Soares, A. L., Oba, A., Rossa, A., Shimokomaki, M. and Ida, E. I. (2009), Broiler transportation conditions in a brazilian commercial line and the occurrence of breast PSE (Pale, Soft, Exudative) meat and DFD-like (Dark, Firm, Dry) meat. Braz. Arch. Biol. Technol., Curitiba, in press.

Lin , J. C. S., Zayas, F.( 1987), Functionality of defatted corn germ proteins in a model system: Fat binding capacity and water retention. J. Food Sci., 53, 13081311.

Mitchell, M. A.; Kettlewell, P. J (1998). Physiological stress and welfare of broiler chickens in transit: solutions not problem! Poultry Science, 77: 18031814.

Olivo, R.; Soares, A. L.; Ida, E. I.; Shimokomaki, M. (2001), Dietary vitamin E inhibits poultry PSE and improves meat functional properties. Journal of Food Biochemistry, 25, 4, 271-283.

Oda, S. H. I., Nepomuceno, A.L., Ledur, M.C, Oliveira, M. C. N., Marin, S. R. R., Ida E. I., Shimokomaki, M. (2009), Quantitative differential expression of alpha and beta ryanodine receptor genes in PSE (Pale, Soft, Exudative) meat from two chicken lines: broiler and layer. Braz. Arch. Biol. Technol., in press

Soares, A. L., Lara, J. A. F., Ida, E. I., Guarnieri, P. D., Olivo, R., Shimokomaki, M. (2002), Variation in the colour of Brazilian Broiler Breast Fillet. Proceedings International Congress of Meat Science Technology, 48, 540-541.
Soares, A. L., Lara, J. A. F., Ida, E. I., Guarnieri, P. D., Olivo, R., Shimokomaki, M. (2003), Influence of Preslaughter Handling Practices on Broiler Meat Color in a Commercial Plant. IFT annual Meeting Book of Abstracts, 201.

Simões, G. S., Oba, A., Matsuo, T., Rossa, A., Shimokomaki, M. and E. I. Ida. (2009), Vehicle thermal microclimate evaluation during brazilian summer broiler transport and the occurrence of pse (pale, soft, exudative) meat. Braz. Arch. Biol. Technol., submitted.

Zhang, L. and Barbut, S. (2005), Effects of regular and modified starches on cooked PSE, normal and DFD chicken breast meat batters. Poultry Science. 84, 789796.

Wang, S. H.; Fernandes, S. M.; Cabral, L. C. (2000), Solubilidade de nitrogênio, dispersibilidade de proteína e propriedades emulsificantes dos extratos hidrossolúveis desidratados de arroz e soja. Ciência $e$ Tecnologia de Alimentos, 20, 12-17.

Woelfel, R. L.; Sams, A. R. (2001), Marination performance of pale broiler breast meat. Poultry Science, 80, 1519-1522.

Woelfel, R. L.; Owens, C. M.; Hirschler, E. M.; Martinez-Dawson, R.; Sams, A. R. (2002), The characterization and incidence of pale, soft, and exudative broiler meat in a commercial processing plant. Poultry Science, 81, 579-584. 


$$
\begin{gathered}
\text { PÁGINA } \\
\text { EM } \\
\text { BRANCO }
\end{gathered}
$$

